\title{
Integrated Effects of Rhizobial Inoculum and Inorganic Fertilizers on Wheat Yield and Yield Components
}

\author{
Muhammad Adnan', Zahir Shah'1, Asif Khan1", Muzamil shah', Gohar Ali Khan1, Azaz Ali1, \\ Nisar Ali Khan', Nouman Saleem², Shah Nawaz' ${ }^{1}$, Saba Akbar', Sonia Samreen', \\ Kanwal Zaib1 \\ ${ }^{1}$ Department of Soil and Environmental Sciences, The University of Agriculture, Peshawar, Pakistan \\ ${ }^{2}$ Department of Plant Breeding and Genetics, The University of Agriculture, Peshawar, Pakistan \\ Email: khansoilscientist27@gmail.com
}

Received 7 May 2014; revised 3 June 2014; accepted 22 June 2014

Copyright (C) 2014 by authors and Scientific Research Publishing Inc. This work is licensed under the Creative Commons Attribution International License (CC BY). http://creativecommons.org/licenses/by/4.0/

(c) (i) Open Access

\section{Abstract}

An experiment was conducted in pots under natural condition with two factor factorial completely randomized design (CRD) (CRD) to investigate the integrated effect of rhizobia inoculums and inorganic fertilizers on growth and yield of wheat crop at The University of Agriculture Peshawar, during 2012-2013. The experiment was comprised of four inoculums (no, lentil, peas and chickpeas) and two NPK levels (recommended 120:90:60 $\mathrm{kg} \cdot \mathrm{ha}^{-1} \& 20 \%$ less of recommended). It was observed that inoculation of wheat by rhizobia significantly increased tillers per plant by a maximum of $42 \%$, plant height by $13 \%$, grain per spike by $16 \%, 100$ grain weight by $10 \%$, biological and grain yield by $10 \%$ over un-inoculated (control) treatment. Among inoculums, peas inoculum was found to be the most efficient for all traits except plant height where chickpea inoculum performed better. Similarly recommended NPK significantly increased tillers per plant by 33\%, plant height by 19\%, grain per spike by $9 \%, 100$ grain weight by 10\%, biological yield by $8 \%$ and grain yield by $10 \%$ compared with $20 \%$ less of recommended NPK. Interactive effect of inoculum $x$ NPK was significant for tillers per plant, grain per spike, grain yield and non-significant for plant height, 100 grain weight and biological yield. However, it was evident from the results that inoculation improved all traits both under recommended and $20 \%$ less of recommended NPK. The persistent good performance of peas and lentil rhizobial inoculation in wheat growth exhibited that this could be used as a plant growth promoting rhizobacteria for wheat and other cereal crops in prevailing soil and climatic conditions.

\section{Keywords}

Yield Components, Rhizobial Inoculum, Wheat, Recommended NPK, Inorganic Fertilizer

\footnotetext{
${ }^{*}$ Corresponding author.

How to cite this paper: Adnan, M., et al. (2014) Integrated Effects of Rhizobial Inoculum and Inorganic Fertilizers on Wheat Yield and Yield Components. American Journal of Plant Sciences, 5, **_**. http://dx.doi.org/10.4236/ajps.2014.513222
} 


\section{Introduction}

Wheat belongs to family Poaceae and genus Triticum and ranks third after maize and rice. On a worldwide scale, wheat covers about $30 \%$ of total cereal products [1]. Pakistan is the ninth largest wheat producing country in the world [2]. Wheat is grown on major areas in Pakistan but its average yield at farmers' fields is still less than the potential [3]. To increase the yields the farmers use mineral fertilizers [4], which are not only very costly but also act as pollutants in many ways. Throughout the world, researchers are facing these threats and they are trying to control this situation by producing alternative substitutes which are more economical, environment friendly and bring sustainable improvement. The best approach to improve crop yield is to use beneficial microbes or plant growth promoting rhizobacteria [5]. Rhizobia can be used as plant growth promoting rhizobacteria (PGPR) in non-legumes [6]. It enhances growth and yield of cereals by production of phytohormones IAA, gibberellins and cytokinins [7], siderophore (iron chelator) [8], enzymes [9], and improves supply of insoluble nutrients such as phosphorus [10] and iron by producing organic acids making these nutrients easily available for plants uptake [11]. It also helps to kill pathogens by producing antibiotics [12], HCN [13] and expolysaccharides [14], and improves morphological characteristics of inoculated roots [15] which increase nutrient and water use efficiency [16], mobilization and efficient uptake of nutrients [11]. Likewise, it increases stress resistance and induction of systemic stress [17] and drought tolerance/resistance by releasing substances like abscisic acid [18] or lumichrome which reduce leaf stomatal opening and decrease transpirational water losses from plants through the leaves. It also improves $\mathrm{N}$ uptake in rice plants [6]. Studies conducted so far regarding the impact of Rhizobium application for cereals are limited and showed specificity of different Rhizobium strains towards cultivar, soil, and environment. Therefore, this pot study was conducted to assess the potential of three Rhizobium species isolated from the root nodules of three locally growing rabbi legumes including peas, lentil and chickpea with two NPK levels (basal dose of NPK and 20\% less than basal of dose NPK) for improving the yield of wheat under greenhouse conditions.

\section{Materials and Methods}

A pot experiment was conducted to investigate the integrated effect of different rhizobial species isolated from winter legumes and inorganic fertilizers on growth and yield of wheat crop at the University of Agriculture, Peshawar during winter 2012-2013. The experiment was comprised of four levels of rhizobial inoculums (control, lentil, peas and chick peas inoculum) and two levels of NPK fertilizers (120:90:60 and 96:72:48 kg.ha ${ }^{-1}$ ) making a total of 8 treatments per replication. The experiment was laid out in Completely Randomized Design with three replications. Pots having $10 \mathrm{~cm}$ radius and $30 \mathrm{~cm}$ depth were filled with five $\mathrm{kg}$ soil. At the time of sowing, pots were amended with required amount of $\mathrm{P}, \mathrm{K}$ and half of $\mathrm{N}$ fertilizer in solution form, $23 \mathrm{~g}$ of Urea, $24.5 \mathrm{~g}$ of DAP and $15 \mathrm{~g}$ SOP were dissolved in $500 \mathrm{ml}$ solution. In this way, 10 and $8 \mathrm{ml}$ of prepared solution was added to pots receiving basal dose and $20 \%$ less than basal dose of NPK, respectively. Half of $\mathrm{N}$ fertilizer was applied at tillering stage in the same manner. Rhizobial inoculum of lentil, peas and chick pea were obtained from National Agricultural Research Council, Islamabad. The seeds of wheat variety Siran were soaked in $20 \%$ concentrated sugar solution, inoculated with required but equal amount of rhizobial inoculums, dried in shade and were sown @ of 8 seeds per pot . Thinning of the pots was performed after 14 days of emergence to maintain 4 seedlings per pot. The pots were irrigated with tap water as per moisture condition. Pots were randomized on weekly basis to avoid side, shade and temperature effect. Data were recorded on agronomic parameter including tillers per plant, plant height, grain per spike, 100 grain weight, biological and grain yield. Grain and biological yield per pot were converted into $\mathrm{Kg} \cdot \mathrm{ha}^{-1}$ on the basis of soil mass $\mathrm{Kg} \cdot \mathrm{ha}^{-1}$ (as soil mass for upper $15 \mathrm{~cm}$ per hectare is $2 \times 10^{6} \mathrm{~kg}$ ). Data recorded were statistically analyzed using ANOVA technique appropriate for completely randomized design and means were compared using LSD test at 5\% level of probability [19].

\section{Results and Discussions}

A pot study was carried out in two factor factorial completely randomized design (CRD) to investigate the integrated effect of rhizobia inoculums and inorganic fertilizers on growth and yield of wheat crop. The soil used for this experiment was silty loam in texture, alkaline in reaction, low in organic matter $(0.73 \%)$, highly calcareous in nature $(13.5 \%)$, non-saline $\left(0.46 \mathrm{~d} \cdot \mathrm{sm}^{-1}\right)$, and low in total nitrogen $(0.08 \%)$ and AB-DTPA extractible Phosphorous $\left(2.25 \mathrm{mg} \cdot \mathrm{kg}^{-1}\right.$ ) contents (Table 1 , Table 2$)$. 
Table 1. Physico-chemical characteristics of soil under investigations.

\begin{tabular}{ccc}
\hline Property & Units & Concentration \\
\hline Textural class & - & Silt loam \\
$\mathrm{pH}$ & - & 7.56 \\
Electrical conductivity $\left(\mathrm{EC}_{\mathrm{e}}\right)$ & $\mathrm{d} \cdot \mathrm{sm}^{-1}$ & 0.46 \\
Lime & $\%$ & 13.5 \\
Organic matter content & $\%$ & 0.73 \\
Total nitrogen content & $\%$ & 0.08 \\
AB-DTPA extractable P & $\mathrm{mg} \cdot \mathrm{kg}^{-1}$ & 2.25 \\
\hline
\end{tabular}

\subsection{Tillers per Plant}

Significant differences were observed among inoculum for tillers per plant (Table 3). Maximum mean tillers per plant of 3.49 was recorded for peas inoculum followed by 3.44 of lentil and 3.05 of chick pea while, minimum mean tillers per plant of 2.77 was recorded for non-inoculated control treatment. These results demonstrated that inoculated treatments produced significantly higher (up to $42 \%$ ) mean tillers per plant than non-inoculated treatments suggested that Rhizobium inoculation had increasing and positive impact on tillers per plant in wheat as reported by [20]. Significant variation of mean tillers per plant in inoculated treatments showed that inoculums varied in their potential as PGPR (plant growth promoting rhizobacteria) for non-leguminous crop as reported by [21] and it may be due to their adoptability to prevailing soil and climatic conditions as reported by [22] who found that Rhizobium strains behave differently according to the soil used. Recommended NPK produced significantly higher (up to 33\%) tillers per plant than 20\% less NPK, it may be due to the inadequacy of NPK in treatments with 20\% less NPK. Interactive effect of inoculum $\times$ NPK showed (Figure 1) significantly higher,maximum mean tillers per plant of 4.46 for treatment of pea's inoculum with recommended NPK while minimum mean tillers per plant of 2.44 were recorded for un-inoculated treatment with $20 \%$ less NPK. Un-inoculated treatment with full NPK produced mean tillers per plant of 2.60 that were statistically similar to that of 2.33, 2.33 and 2.27 for inoculated treatments of peas, chickpea and lentil with $20 \%$ less NPK respectively. These results suggested that inoculation of wheat seed with Peas, chickpeas and Lentil Inoculums can contribute 20\% NPK to the system and thus may reduce the use of mineral NPK fertilizer up to $20 \%$ for wheat crop under prevailing soil conditions, this may be due to the ability of Rhizobium inoculums to act as PGPR (plant growth promoting rhizobacteria), as it solubilize/mobilize and bind nutrients from organic and inorganic sources as reported by [23].

\subsection{Plant Height (cm)}

Significant differences were recorded in inoculum for plant height (Table 3). Plant height of 73.33, 69.99 and $72.66 \mathrm{~cm}$ were recorded for chickpeas, peas and lentil inoculum respectively which were statistically at par, however minimum plant height of 64.66 was observed for control. These results revealed that inoculation enhanced plant height by $9 \%$ over non-Inoculated control. [24] also observed increase in wheat plant height by rhizobial inoculation. Treatments with full NPK showed significantly higher plant height of $72.25 \mathrm{~cm}$ than that of $68 \mathrm{~cm}$ of $20 \%$ less NPK, this may be due to the inadequate availability of NPK at 20\% less NPK. Interaction of inoculum and NPK for plant height was non-significant but it showed a trend which demonstrated that inoculation increase plant height at both recommended and $20 \%$ less of recommended NPK. These findings suggested that inoculation of rhizobia along with full NPK is more effective than inoculation with $20 \%$ less NPK.

\subsection{Grain per Spike}

Significant differences were observed in mean grains per spike for main effect of inoculum (Table 4). Maximum mean grains per spike of 43.77 were recorded for peas inoculum. Lentil inoculum showed 41.78 grain per spike which was significantly higher than that of 40.66 grain per spike of chickpea and lower than that of peas 
Table 2. ANOVA and Sum of Squares of Tillers per plant, Plant height, Grain per spike, 100 grain weight, Grain yield and Biological yield.

\begin{tabular}{|c|c|c|c|c|c|c|c|}
\hline \multirow[t]{2}{*}{ SOV } & \multirow[t]{2}{*}{ DF } & \multicolumn{6}{|c|}{ Sum of Square } \\
\hline & & Tillers per plant & Plant Height & Grain per Spike & 100 grain weight & Grain yield & Biological yield \\
\hline Inoculums & 3 & $4.64^{* *}$ & $279.33^{* *}$ & $112.39^{* *}$ & $0.618^{* *}$ & $501,965^{* *}$ & $3,733,736^{* *}$ \\
\hline NPK & 1 & $5.34^{* *}$ & $104.17^{* *}$ & $61.25^{* *}$ & $1.219^{* *}$ & $739,206^{* *}$ & $2,250,325^{* *}$ \\
\hline Inoculums ${ }^{*}$ NPK & 3 & $0.76^{* *}$ & $7.30^{*}$ & $4.73^{* *}$ & $0.082 *$ & $204,637^{* *}$ & $109,634^{*}$ \\
\hline Error & 16 & 1.02 & 66.47 & 5.84 & 0.718 & 191,584 & $2,110,745$ \\
\hline Total & 23 & 11.78 & 457.27 & 184.2 & 2.637 & $1,637,391$ & $8,204,440$ \\
\hline $\mathrm{CV}$ & - & 7.66 & 2.91 & 1.55 & 4.49 & 1.00 & 4.47 \\
\hline
\end{tabular}

${ }^{* *}$ Significant and ${ }^{*}$ Non Significant.

Table 3. Tillers per plant and plant height as influenced by applied treatments.

\begin{tabular}{ccccc}
\hline Inoculum & Tillers per & \% Increase & Plant height & \% Increase \\
\hline & Plant & Decrease & $\mathbf{( c m )}$ & Decrease \\
\hline Control & $2.77 \mathrm{c}$ & - & $64.66 \mathrm{~b}$ & - \\
Lentil & $3.44 \mathrm{~b}$ & 24 & $72.66 \mathrm{a}$ & 12 \\
Peas & $3.49 \mathrm{a}$ & 42 & $69.99 \mathrm{a}$ & 8 \\
Chickpeas & $3.05 \mathrm{c}$ & 10 & $73.33 \mathrm{a}$ & \\
LSD (0.05) & 0.31 & & 3.4 & \\
NPK & & & & - \\
Full & $3.77 \mathrm{a}$ & - & $72.25 \mathrm{a}$ & -19 \\
20\% less & $2.83 \mathrm{~b}$ & -33 & $68.00 \mathrm{~b}$ & \\
Sig. level & $*$ & & $*$ &
\end{tabular}

I*NPK Interaction

Sig. level * (Figure 1) NS

${ }^{*}$ Means with different letter(s) in columns are significantly different at $\mathrm{P} \leq 0.05$.

Table 4. Grain per spike and 100 grain weight as influenced by applied treatments.

\begin{tabular}{|c|c|c|c|c|}
\hline Inoculum & Grain per & \% Increase & 100 grain weight & \% Increase \\
\hline spike & Decrease & (g) & Decrease & \\
\hline Control & $37.55 \mathrm{~d}$ & - & $4.51 \mathrm{~b}$ & - \\
\hline Lentil & $41.78 b$ & 8 & 4.76ab & 6 \\
\hline Peas & $43.77 a$ & 16 & $4.95 \mathrm{a}$ & 10 \\
\hline Chickpeas & $40.66 c$ & 4 & $4.65 a$ & 3 \\
\hline LSD (0.05) & 0.74 & & 0.26 & \\
\hline \multicolumn{5}{|l|}{ NPK } \\
\hline Full & $40.66 a$ & - & $4.94 a$ & - \\
\hline $20 \%$ less & $37.46 \mathrm{~b}$ & -9 & $4.49 \mathrm{~b}$ & -10 \\
\hline Sig. level & * & & * & \\
\hline \multicolumn{5}{|c|}{$I^{*} N P K$ Interaction } \\
\hline Sig. level & *(Figure 2) & & NS & \\
\hline
\end{tabular}

${ }^{*}$ Means with different letter(s) in columns are significantly different at $\mathrm{P} \leq 0.05$. 


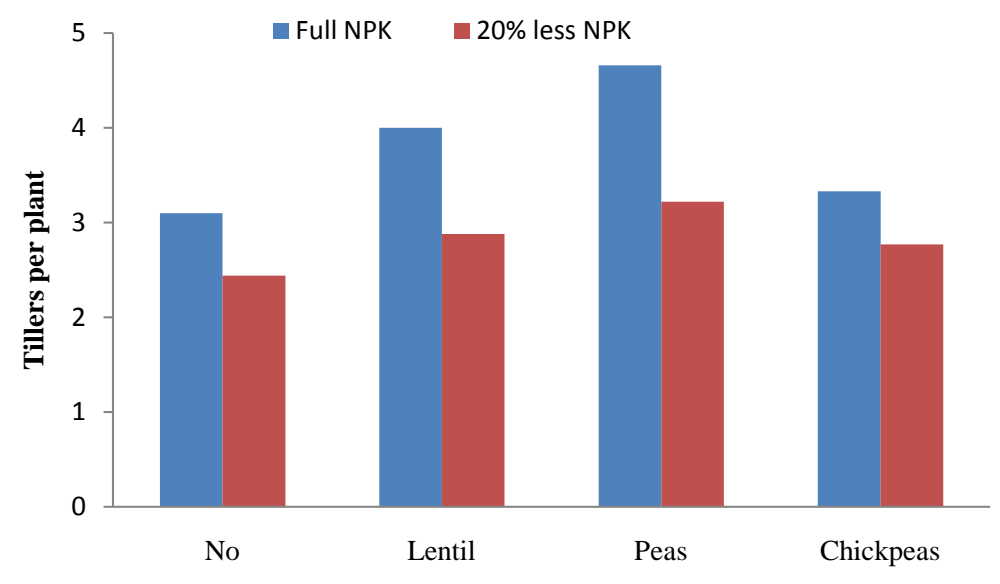

Figure 1. Tillers per plant as influenced by interaction of inoculum and NPK.

inoculum. Minimum mean grains per spike of 37.55 were recorded for non-inoculated (control) treatment. These results showed that wheat seed inoculated with peas Rhizobium inoculum produced significantly higher mean grains per spike (up to 16\%) than non-inoculated treatments, thus suggested that Rhizobium inoculation had increasing and positive impact on grains per spike in wheat as reported by [25]. Significant variation of mean grains per spike in inoculated treatments showed that inoculums varied in their potential as PGPR (plant growth promoting rhizobacteria) for non-leguminous crop as reported by [21] and it may be due to their adoptability to prevailing soil and climatic conditions as reported by [22] who found that Rhizobium strains behave differently according to the soil used. Recommended NPK produced significantly higher mean grains per spike of 40.66 than 37.44 of $20 \%$ less NPK, it may be due to the inadequacy of NPK in treatments with $20 \%$ lees of recommended NPK. Interaction of inoculum and NPK was significant for grain per spike (Figure 2). On the average maximum grain per spike of 43.77 were recorded for Peas inoculum with full recommended NPK while minimum grain per spike of 35.55 was recorded for control (no inoculum) with $20 \%$ less of recommended dose of NPK. It was also evident from the result that inoculation of rhizobia increased grain per spike at both recommended and $20 \%$ less of recommended NPK.

\subsection{Grains Weight}

Data recorded for mean 100 grain weight (Table 4) showed significant differences for main effect of inoculums, NPK and non-significant variation for the interaction of inoculum and NPK. Maximum mean 100 grain weight of $4.95 \mathrm{~g}$ was recorded for peas inoculum followed by $4.76 \mathrm{~g}$ of lentil and $4.65 \mathrm{~g}$ of chick pea while minimum mean 100 grain weight of $4.51 \mathrm{~g}$ was recorded for non-inoculated (control) treatments. These results demonstrated that inoculated treatments produced significantly higher (up to 10\%) 100 g weight than non-inoculated treatments suggested that Rhizobium inoculation had increasing and positive impact on 100 grain weight as reported by [19]. Significant variation of mean 100 grain weight in inoculated treatments showed that inoculums varied in their potential as PGPR (plant growth promoting rhizobacteria) for non-leguminous crop as reported by [21]. Full NPK produced significantly higher (up to $10 \%$ ) mean 100 grain weight of $4.94 \mathrm{~g}$ than $4.49 \mathrm{~g}$ of 20\%less NPK. The interactive effect of inoculum and NPK was non-significant but showed a trend that inoculation of wheat by rhizobia enhanced 100 grain weight at both full and $20 \%$ less of recommended NPK.

\subsection{Grain Yield}

Differences recorded for inoculum, NPK and their interaction were significant (Table 5). Maximum grain yield of $2949 \mathrm{~kg} \cdot \mathrm{ha}^{-1}$ was recorded for peas inoculum followed by $2769 \mathrm{~kg} \cdot \mathrm{ha}^{-1}$ of lentil, $2616 \mathrm{~kg} \cdot \mathrm{ha}^{-1}$ of chickpeas while minimum grain yield of $2588 \mathrm{~kg} \cdot \mathrm{ha}^{-1}$ was recorded for un-inoculated treatments. These results demonstrated that inoculated treatments enhanced grain yield (up to 14\%) significantly over non-Inoculated treatments, same results were also found by [26]. Significant variation among the inoculums for grain yield may be due to variation in the adaptability of inoculum to prevailing soil and climatic condition as reported by [22]. Treatments with full NPK showed significantly higher (up to 14\%) grain yield of $2909 \mathrm{~kg} \cdot \mathrm{ha}^{-1}$ than that of $2558 \mathrm{~kg} \cdot \mathrm{ha}^{-1}$ of 


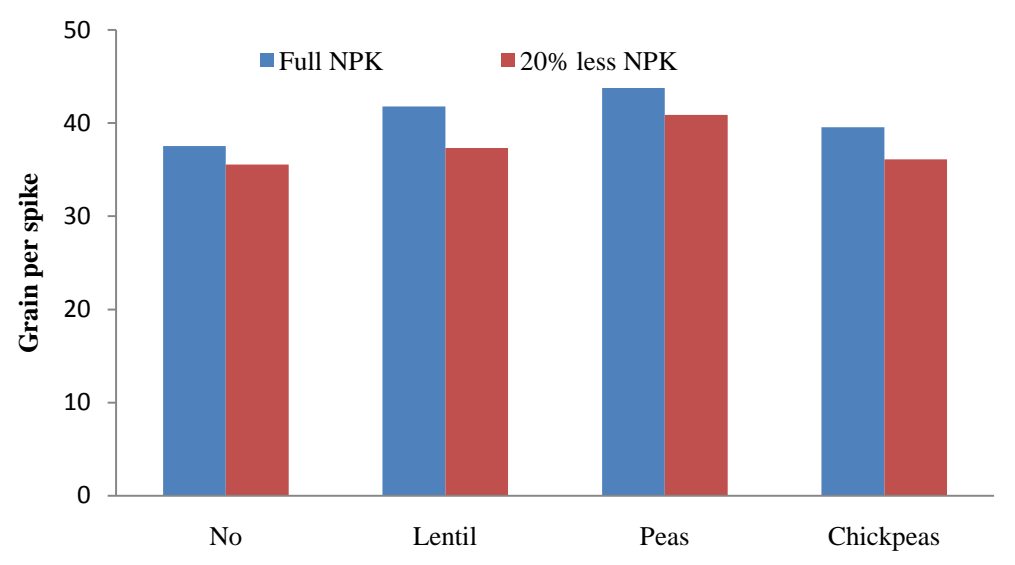

Figure 2. Grain per spike as influenced by interaction of inoculum and NPK.

Table 5. Grain and biological yield of wheat as influenced by applied treatments.

\begin{tabular}{|c|c|c|c|c|}
\hline Inoculum & Grain yield & $\%$ Increase & Biological yield & $\%$ Increase \\
\hline & $\left(\mathrm{Kg}^{\prime} \mathrm{ha}^{-1}\right)$ & Decrease & $\left(\mathbf{k g} \cdot \mathrm{ha}^{-1}\right)$ & Decrease \\
\hline Control & $2588 c$ & - & $7479 b$ & - \\
\hline Lentil & $2769 b$ & 7 & $8245 a$ & 10 \\
\hline Peas & 2949a & 14 & $8650 a$ & 14 \\
\hline Chickpeas & $2616 c$ & 1 & $8231 \mathrm{a}$ & 10 \\
\hline LSD (0.05) & 133.93 & & 444 & \\
\hline \multicolumn{5}{|l|}{ NPK } \\
\hline Full & 2909a & - & 8433a & - \\
\hline $20 \%$ less & 2558b & -14 & $7820 \mathrm{~b}$ & -8 \\
\hline Sig. level & $*$ & & * & \\
\hline \multicolumn{5}{|c|}{ I*NPK Interaction } \\
\hline Sig. level & "(Figure 3) & & NS & \\
\hline
\end{tabular}

\footnotetext{
${ }^{*}$ Means with different letter(s) in columns are significantly different at $\mathrm{P} \leq 0.05$.
}

$20 \%$ less NPK, this may be due to the inadequate availability of NPK at $20 \%$ less NPK. Significant interactive effect of inoculum and NPK exhibited that, on the average maximum plant grain yield of 3280 were recorded for Peas inoculum with full recommended NPK, while minimum of 2475 was recorded for control (no inoculum) with $20 \%$ less of recommended dose of NPK. It was also evident from the result that inoculation of rhizobia increased grain yield at both recommended and 20\% less of recommended NPK. These results suggested that Rhizobium inoculation can be used as PGPR (plant growth promoting rhizobacteria) for wheat crop in prevailing soil and climatic conditions.

\subsection{Biological Yield}

Variations observed for biological yield as affected by inoculum and NPK were significant. Statistically at par biological yield of 8650, 8245 and $8231 \mathrm{~kg} \cdot \mathrm{ha}^{-1}$ were recorded for peas, lentil and chickpeas inoculums respectively, while minimum of $7479 \mathrm{~kg} \cdot \mathrm{ha}^{-1}$ was recorded for un-inoculated (control) treatment. These results demonstrated that inoculated treatments enhanced biological yield (up to 14\%) significantly over non-Inoculated treatments (Table 5) same results were also found by [24]. Significant variation among the inoculums for biological yield may be due to variation in the adaptability of inoculum to prevailing soil and climatic condition as 


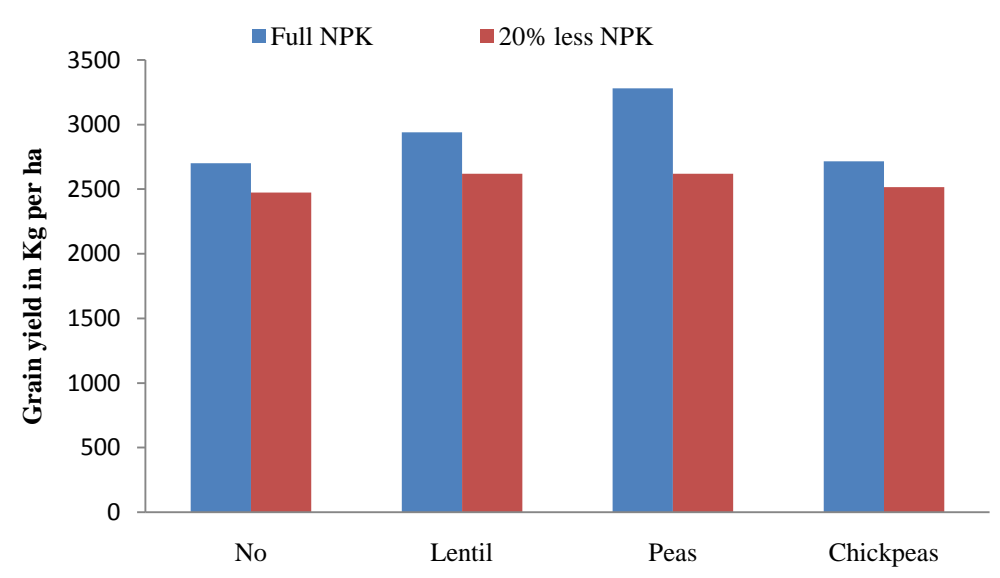

Figure 3. Grain yield as influenced by interaction of inoculum and NPK.

reported by [22]. Treatments with recommended NPK showed significantly higher (up to 8\%) biological yield of $8433 \mathrm{~kg} \cdot \mathrm{ha}^{-1}$ than that of $7820 \mathrm{~kg} \cdot \mathrm{ha}^{-1}$ of $20 \%$ less of recommended NPK, this may be due to the inadequate availability of NPK at 20\% less NPK. 1st order interaction of NPK and inoculum (NPK x inoculums) for biological yield indicated that non-inoculated treatment with full NPK produced significantly lower biological yield than chick pea, peas and Lentil Inoculum with $20 \%$ less of recommended NPK. These findings suggested that inoculation of wheat seed with Peas and Lentil Inoculums can contribute 20\% NPK and thus may reduce the use of mineral NPK fertilizer up to $20 \%$ for wheat crop under prevailing soil conditions. These findings suggested that inoculation of rhizobia along with recommended NPK is more effective than inoculation with $20 \%$ less of recommended NPK.

\section{Conclusion}

It was concluded that inoculation of wheat with rhizobia enhanced wheat yield component at both recommended and $20 \%$ less of recommended NPK. Furthermore, it was also demonstrated by results that $20 \%$ less of recommended NPK along with peas and lentil inoculation had similar or better role than full recommended NPK alone in growth and yield of wheat crop.

\section{References}

[1] Fageria, N.K., Baligar, V.C. and Jones, C.A. (1997) Wheat and Barley in Growth and Mineral Nutrition of Field Crops. Marcel Dekker, 243-287.

[2] Tuino, S.D., Korejo, M.N., Jarwar, A.D. and Waggan, M.R. (2006) Studies on Indigenous Andexotic Weed Competition in Wheat. Pakistan Journal of Agriculture, Agricultural Engineering and Veterinary Sciences, 22, 112-116.

[3] Mann, R.A., Jehangir, W.A. and Masih, I. (2004) Improving Crop and Water Productivity of Rice-Wheat System in Punjab, Pakistan. Proceedings of the 4th International Crop Science Congress, Brisbane, 25 September-2 October 2004.

[4] Anonymous (2002) Fertilizers Review. Publication No.3/2002.NFDC, Islamabad.

[5] Defreitas, J.R. and Germida, J.J. (1990) Plant Growth Promoting Rhizobacteria for Winter Wheat. Canadian Journal of Microbiology, 36, 265-272. http://dx.doi.org/10.1139/m90-046

[6] Yanni, Y.G., Rizk, R.Y., Corich, V., Squartini, A., Ninke, K., Philip-Hollingsworth, S., Orgambide, G., De Bruijn, F., Stoltzfus, R., Buckley, D., Schmidt, T., Mateos, P.F., Ladha, J.K. and Dazzo, F.B. (1997) Natural Endophytic Association between Rhizobium Leguminosarum bv. Trifolii and Rice Roots and Assessment of Its Potential to Promote Rice Growth. Plant and Soil, 194, 99-114. http://dx.doi.org/10.1023/A:1004269902246

[7] Zahir, Z.A., Yasin, H.M., Naveed, M., Anjum, M.A. and Khalid, M. (2010) Tryptophan Application Enhances the Effectiveness of Rhizobium Inoculation for Improving Growth and Yield of Mung Bean [Vigna radiate (L.) Wilczek]. Pakistan Journal of Botany, 42, 1771-1780.

[8] Meyer, J.M. (2000) Pyoverdines: Pigments, Siderophores and Potential Taxonomic Markers of Fluorescent Pseudomonas sp. Archives of Microbiology, 174, 135-142. http://dx.doi.org/10.1007/s002030000188 
[9] Yang, S.F. and Hoffman, N.E. (1984) Ethylene Biosynthesis and Its Regulation in Higher Plants. Annual Review of Plant Physiology, 35, 155-189. http://dx.doi.org/10.1146/annurev.pp.35.060184.001103

[10] Fatima, Z., Zia, M. and Chaudhary, M.F. (2006) Effect of Rhizobium Strains and Phosphorus on Growth of Soybean (Glycine max) and Survival of Rhizobium and P Solubilizing Bacteria. Pakistan Journal of Botany, 38, 459-464.

[11] Biswas, J.C., Ladha, J.K. and Dazzo, F.B. (2000) Rhizobia Inoculation Improves Nutrient Uptake and Growth of Lowland Rice. Pakistan Journal of Botany, 164, 1644-1650. http://dx.doi.org/10.2136/sssaj2000.6451644x

[12] Antoun, H. and Provest, D. (2000) PGPR Activity of Rhizobium with Non-Legumes Plants. http://www.ag.auburn.edu/argentina/pdfmanuscript/tableofcontents.pdf.

[13] Antoun, H., Beauchamp, C.J., Goussard, N., Chabot, R. and Lalande, R. (1998) Potential of Rhizobium and Rradyrhizobium Species as Plant Growth Promoting Rhizobacteria on Non-Legumes: Effect on Radishes (Raphanus sativus L.). Plant and Soil, 204, 57-67. http://dx.doi.org/10.1023/A:1004326910584

[14] Goyal, V., Chetal, S. and Nainawatee, H.S. (1986) Alteration in Rhizobium trifolli Catalase under Water Stress. Folia Microbiologica, 31, 164-166. http://dx.doi.org/10.1007/BF02926835

[15] Biswas, J.C. (1998) Effect of Nitrogen Fixing Bacteria on Growth Promotion of Lowland Rice (Oryza sativa L.). Ph. D., Thesis, Department of Soil Science University of Phillipines, Los Banos.

[16] Okon, Y. and Kapulnik, Y. (1986) Development and Function of Azospirillum-Inoculated Roots. Plant and Soil, 90, 316. http://dx.doi.org/10.1007/BF02277383

[17] Yang, J., Kloepper, J.W. and Ryu, C.M. (2006) Rhizosphere Bacteria Help Plant Tolerance to Abiotic Stress. Trends in Plant Science, 14, 1-4. http://dx.doi.org/10.1016/j.tplants.2008.10.004

[18] Steel, R.G.D. and Torrie, J.H. (1980) Principles and Procedures of Statistics. A Biometrical Approach. McGraw-Hill, New York.

[19] Mehboob, I., Zahir, Z.A., Arshad, M., Tanveer, A. and Azam, F. (2011) Growth Promoting Activities of Different Rhizobium spp., in Wheat. Pakistan Journal of Botany, 43, 1643-1650.

[20] Phillips, D.A. and John, G.T. (1970) Cytokinin Production by Rhizobium japonicum. Physiologia Plantarum, 23, 10571063. http://dx.doi.org/10.1111/j.1399-3054.1970.tb08880.x

[21] Solaiman, A.R.M., Hossain, G.M.A. and Mia, M.A.B. (2011) Effect of Rhizobium on Growth and Biomass Production of Rice. Bangladesh Journal of Microbiology, 28, 64-68.

[22] Hilali, A., Prévost, D., Broughton, W. and Antoun, H. (2001) Effects of Inoculation with Rhizobium leguminosarum Biovar Trifolii on Wheat Cultivated in Clover Crop Rotation Agricultural Soil in Morocco. Canadian Journal of Microbiology, 47, 590-593.

[23] Vargas, L.K., Lisboa, B.B., Giongo, A., Beneduzi, A. and Passaglia, L.M.P. (2010) Potential of Rhizobia as Plant Growth-Promoting Rhizobacteria. Biomedical and Life Sciences, Microbes for Legume Improvement, 137-155.

[24] Mehboob, I., Zahir, Z.A., Arshad, M., Tanveer, A. and Khalid, M. (2012) Comparative Effectiveness of Different Rhizobium sp. for Improving Growth and Yield of Maize (Zea mays L.). Soil Environment, 31, 37-46.

[25] Afzal, A. and Bano, A. (2008) Rhizobium and Phosphate Solubilizing Bacteria Improve the Yield and Phosphorus Uptake in Wheat (Triticum aestivum). International Journal of Agriculture and Biology, 10, 1560-1566.

[26] Husssain, M.B., Mehboob, I., Zahir, Z.A., Naveed, M. and Asghar, H.N. (2009) Potential of Rhizobium spp. for Improving Growth and Yield of Rice (Oryza sativa L.). Soil Environment, 28, 49-55. 
Scientific Research Publishing (SCIRP) is one of the largest Open Access journal publishers. It is currently publishing more than 200 open access, online, peer-reviewed journals covering a wide range of academic disciplines. SCIRP serves the worldwide academic communities and contributes to the progress and application of science with its publication.

Other selected journals from SCIRP are listed as below. Submit your manuscript to us via either submit@scirp.org or Online Submission Portal.
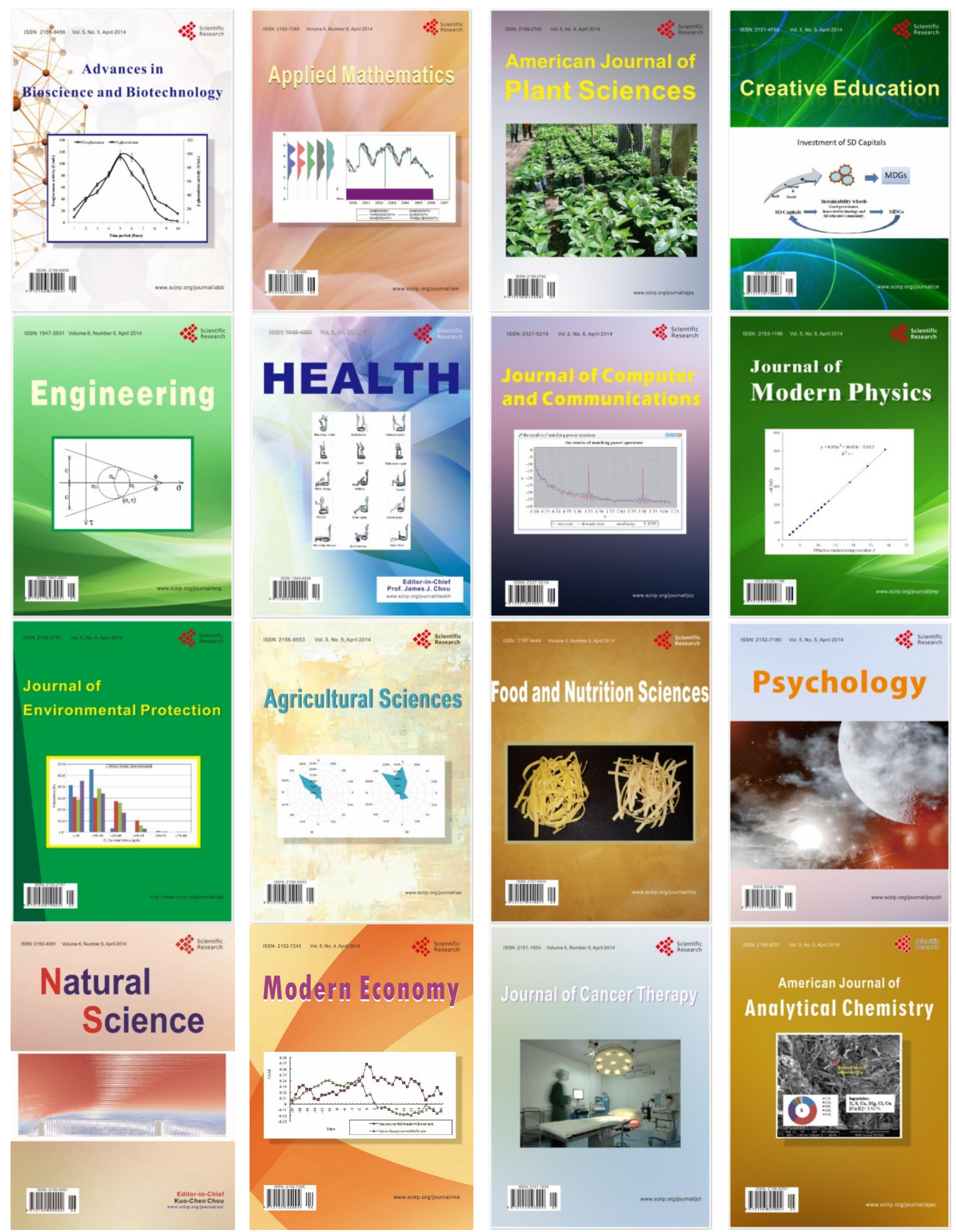